\title{
7. 生理
}

\section{PG-001ストレス暴露時の実行系機能に与える 共作業者の影響一情動ストループ課 題時の事象関連電位を用いた検討一}

○西村 律子 ${ }^{1,2}$, 浅岡 章一 ${ }^{1,2}$, 平島 太郎 3

('江戸川大学, ${ }^{2}$ 江戸川大学睡眠研究所, ${ }^{3}$ 愛知淑徳大学)

キーワード：情動ストループ，共作業者，事象関連電位

他者の存在が脅威状況における実行機能に及ほすす効果を明らかにする ために，同じ課題に同室で取り組む他者（共作業者）の存在が，情動ス トループ課題の成績㧍よび脅威刺激呈示前の事象関連電位（刺激前陰性 電位；SPN）に与える影響を検討した。情動ストループ課題では，赤あ るいは白の凝視点が $2500 \mathrm{~ms}$ 呈示され，凝視点が赤の場合は続いて不快 画像が, 白の場合は中性画像が $1000 \mathrm{~ms}$ 呈示された。画像の呈示後, ス トループ課題（色名単語と印字の色の組み合わせ：一致・不一致・中立） を実施した。課題中の脳波は頭皮上25個所より記録された。その結果，共 作業者がいる場合（共作業条件）では，不一致条件における反応時間が 単独で課題に取り組む場合（単独条件）と比較して短縮する一方で，工 ラー率は上昇していた。呈示された画像の効果は第 1 ブロックのみで認 められ，不快刺激呈示時にエラー率が上昇していた。そこで，第 1 ブロッ クの脳波を解析したところ，単独条件の場合には中心部の SPN 振幅に左 右差 (左半球く右半球) が認められたが, 共作業条件では左右差は認め られなかった。この左右差の消失は画像刺激へのネガティブな予期の低 減を反映している可能性が考えられた。

\section{PG-003＼cjkstart座圧測定による感情状態推定}

○村 司 ${ }^{1}$, 植山 七海,"\#, 片山 順一2

( ${ }^{1}$ 大阪大学, ${ }^{2}$ 関西学院大学)

キーワード：接近回避, 感情, 計測方法

本研究ではセンサの装着が不要であり, かつ着席中に常時デー夕の取 得が可能な座圧から心理状態のセンシングを試みた。特に, 感情状態に 対応した接近回避行動に着目し, 着席時の前後の重心移動からポジティ ブ感情とネガティブ感情のセンシングを試みた。この目的のため, 被験 者19名からポジティブ動画（乳児が紙を次々に破って笑っている動画）, ネガティブ動画 (ムカデがゴキブリを捕食している動画), ニュートラル 動画（工場排水が流れる動画）視聴時の座圧を測定した。動画の順序は 被験者間でカウンターバランスし，座圧は，椅子に設置したシート状の センサで測定した。測定した座圧分布から面圧中心点を計算し，動画視 聴時の前後の重心移動を接近回避行動の指標とした。また，多面的感情 状態尺度短縮版を用い動画に対する主観指標を測定した。実験の結果, 動 画の感情価に対応し主観指標は変化した。さらに，ネガティブ動画視聴 時のみ，動画を呈示するデイスプレイから身体を遠ざける後方への重心 移動が, 動画視聴早期から一貫してみられた。これらの結果は, 座圧を 測定することでセンサ装着の負担や作業の中断なくネガティブ感情のセ ンシングが可能であることを示唆する。

連絡先 E-mail：kimura@ai.sanken.osaka-u.ac.jp

注）＃印は日本心理学会会員以外であることを示す。

PG-002＼cjkstart随意呼吸時の呼吸位相が恐怖顔の検 出成績に及ぼす効果

○水原 啓太 ${ }^{1}$, 入戸野 宏

( 大阪大学)

キーワード : 呼吸位相, 情動, 知覚

自然に呼吸をしているときに鼻から息を吸うと扁桃体の活動が高まり， 息を吐くときに比べて，恐怖顔に対して素早く反応できることが報告さ れている (Zelano, et al., 2016)。扁桃体は恐怖情動の処理において重要 な役割を持つ脳部位である。恐怖顔に素早く反応できるのは, 吸気時に は脅威刺激に対する感度が高くなっているからと考えられる。本研究で は，随意的に呼吸を調整するときにも，呼吸位相（吸気・呼気）によっ て恐怖顔の弁別感度が異なるのかについて検討した。日本人の真顔と恐 怖顔をモーフィングすることで，強度の異なる 3 種類の恐怖顔を作成し た。実験は一試行一呼吸で実施した。参加者は試行開始のキーを押すと 同時に息を吸い始め（吐き始め），その直後に顔判断課題を行った。真顔 と恐怖顔を左右に並べて $100 \mathrm{~ms}$ 間提示し，恐怖顔だと思うほうを選ぶ ように求めた。実験の結果, 恐怖顔の割合が高い顔ほど正答率は高くなっ たが，吸気時と呼気時で成績に差はなかった。呼吸位相の効果が得られ なかった原因として，刺激提示の夕イミングが一定であったことや，自 然呼吸と随意呼吸の違いがあると考えられる。

\section{PG-004緑化空間での植物静観が疲労感に及 ぼす影響一生体指標を用いた評価一}

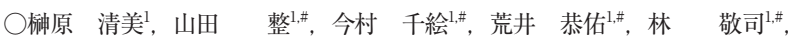
大平 英樹 ${ }^{2}$, 山口 雄平 ${ }^{1, \#}$

( ${ }^{1}$ トヨ夕自動車, ${ }^{2}$ 名古屋大学 $)$

キーワード : 緑化空間, 疲労, 生体指標

心身ともに良好に過ごせる，いわゆる“Well-being”実現につながる 技術として, 自然を感じられる緑化空間がもつ疲労回復効果に着目して いる。同効果を客観的, 統合的に評価するため, 主観評価の他, 自律神 経機能を心電図・指尖脈波・呼吸, 脳活動を NIRS（浜松ホトニクス, tNIRS-1), 生化学系を唾液中バイオマーカーにより計測した。葉の形状 などが異なる 3 種類の緑化空間および緑なし空間（ネガティブコントロー ル：ネガ）の計 4 種類を作製して比較した。被験者（女性 8 名）はそれ ぞれ 4 日間, 同じ時間帯に実験参加し, 座位安静の計測（安静）の後, 軽 い疲労課題としてVR ゲームを10分間行い (VR)，4 種類のいずれかの 空間へ入って20分間，植物を静観した（試験空間）。主観評価の「心地よ さ」は安静に比べて VR 後に低下し，ネガ以外の 3 部屋の試験空間後に 改善する傾向が認められた。生体指標の心拍変動係数 CVRR 等の安静に 対する変化量 (安静と試験空間の差) の対応は空間条件によって異なり, 植物群によって異なる緑化空間の効果が示唆された。以上から主観評価, 生体指標ともに緑化空間の疲労回復効果につながる知見が得られた。 